\title{
Highly refractory ultramafic complex from Hong'an, western Dabie orogen, central China: Ophiolite or SCLM fragments?
}

\author{
YUCHEN LIU ${ }^{1}$, CHANGQIAN MA $^{1,2 *}$
}

${ }^{1}$ School of Earth Sciences, China University of Geosciences (Wuhan) (chenyliugeology@hotmail.com)

${ }^{2}$ State Key Laboratory of Geological Proceses and Mineral Resources, China Unversity of Geosciences (Wuhan)

(*correspondence: $\underline{\text { cqma@ } a, c u g . e d u . c n)}$

Ultramafic rocks outcropped within orogenic belt or collision margin always attract numerous attention. Most natural objects are commonly hydrated and compositionally modified, making up a special and complicated type which worth advanced study onto their origins, records of fluid/melt alterations and tectonic evolution. In our research of a set of ultramafic rocks emplaced within Mesoproterozoic schists in Hong'an, Western Dabie orogen, central China, we may establish a new discussion about the unfiled ancient mantle rocks by bulk geochemistry and mineral-microanalysis on chromite, olivine and other critical minerals.

The ultramafic massif consists of serpentinized peridotite and minor amphibolite. Peridotites were highly hydrated with two main lithologies of harzburgite and dunite recognized. Low $\mathrm{SiO}_{2}$ and $\mathrm{CaO}, \mathrm{Al}_{2} \mathrm{O}_{3}$ contents with highly depleted, "U" shaped REE pattern imply a inherited highly refractory signiture of typical mantle wedge peridotite without refertilization. Olivine relicts in dunites show consistently high Fo content (96 97). Chromites derive from both harzburgite and dunite, occurring mainly as disseminated discrete grains with zoning texture under microscope. Two types of chromites are documented with high $\mathrm{Cr} \#, \mathrm{Mg} \#$ and low $\mathrm{TiO}_{2}(<0.058 \mathrm{wt} \%)$ showing multiple evolution stages: 1) relatively Al-riched chromite core $\left(\mathrm{Al}_{2} \mathrm{O}_{3}=15.7 \sim 17.5 \mathrm{wt} \%, \quad \mathrm{Cr} \#=0.67 \sim 0.70, \quad \mathrm{Mg} \#=0.59 \sim 0.62\right)$ with a rim of increased $\mathrm{Cr} \#(\sim 0.76)$, retaining the primary spinel phase and a $\mathrm{Cr}$ enrichment process; 2) Cr-riched chromite core $\quad(\mathrm{Cr} \# 0.81 \sim 0.99, \quad \mathrm{Mg} \#=0.38 \sim 0.55) \quad$ with decreasing $\mathrm{Cr} \#$ attributing to retrograde metamorphism. These suggest a primitive high degree of melting character and an influence of boninitic melts under forearc mantle wedge environment, which appears similar with the mechanism of ophilitic chromitites in SSZ. Meanwhile lizardite, brucite and dolomite of early serpentinization show affinity to fluids derived from oceanic slab. We propose the ultramafic massif in Hong'an orogen represented SCLM fragments involved into an ancient oceanic subduction channel and emplaced along. 